\title{
India to offer microloans for people living with HIV
}

I nia will tentatively dip a toe in the waters of microloans for people living with HIV with the creation of a pilot project to establish small businesses in the state of Manipur.

It's hoped that the initiative will allow people living with HIV to create small embroidery or weaving businesses, or even set up grocery stores. But with 38000 people in the state, or a projected $19.8 \%$ of its HIV positive population, having contracted the virus through intravenous drug use, observers are urging caution.

"There are two issues which we need to be cautious about. First, when the majority of the HIV infected people in Manipur are injecting drug users, it's difficult to say whether they would use the loan amount properly. So, there must be some monitoring system to look after the situation so that these people can't waste the money for buying more drugs," says Swapan Jana, secretary of the Society for Social Pharmacology, a nongovernmental advocacy group.

"Secondly, it's crucial to see how long these banks take to implement this loan scheme throughout India," he adds. "India's total HIV burden is huge compared to the state of Manipur only."

The financial devastation of that burden is likely huge as well, if the situation in Manipur is any indication. HIV has financially crippled people in Manipur, according to a study conducted by the National Council of Applied Economic Research (http://data.undp.org.in/hiv /state-wise/Manipur(factsheet).pdf).

"About 43 percent of the HIV households have either borrowed or liquidated their assets to cope with the increased financial burden," the study stated. "It is observed that the head count ratio of poverty is higher in the case of the HIV households in both the urban and rural areas. The poor among the HIV households are under serious constraint in attempting to meet their consumption expenditure."

India's embryonic microloan initiative will see the United Bank of India and

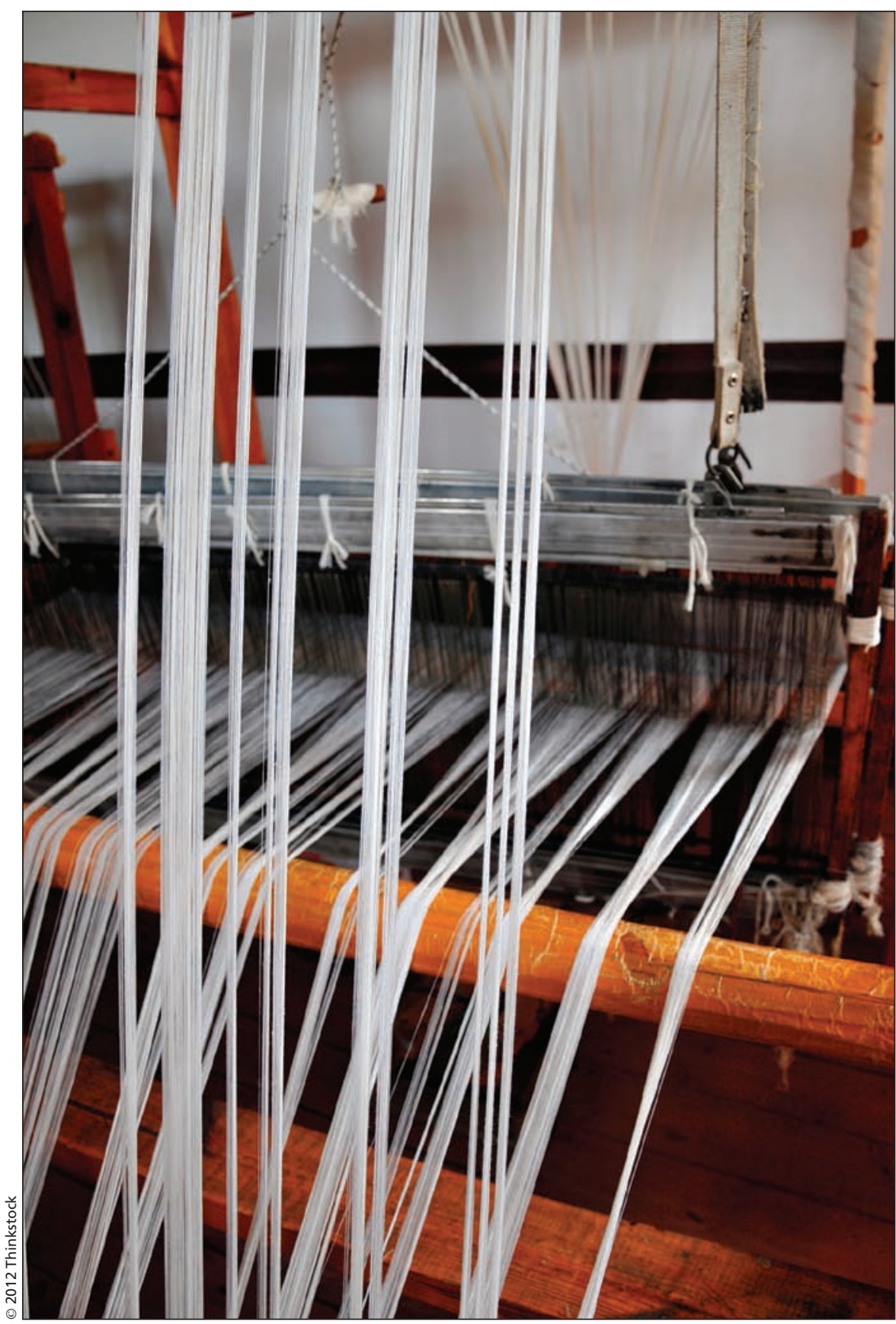

Among loan applications that have already been submitted by people living with HIV is one from a woman who is seeking to launch a weaving enterprise.

State Bank of India offer up to 500000 rupees to those who meet eligibility criteria - that is, to natives of India living with HIV who have "a valid work plan or project." Thus far, proposals have been received from two women living with
HIV. One hopes to establish an embroidery shop, while the other is seeking to launch a weaving enterprise.

"We will also be looking at providing loans to family members of HIV patients to ease their financial burden," 
says R. Bhattacharjee, chief general manager for the United Bank of India.

Providing loans to HIV positive people isn't a great financial risk, says Thotngam Jamang, deputy general manager of the Reserve Bank of India, which oversees commercial operation of banks in India. "Many of them have skilled knowledge and are well versed in traditional economic activities such as crafts, et cetera. But there are few employment opportunities. These loans will support entrepreneurship." Jamang adds that the banks will arrange regular health checkups for loan recipients.

Microloans for people living with HIV have become extremely common in several nations within Africa, Asia and Latin America, in part because of a 2009 decision by the United States government to provide start-up funding under the President's Emergency Fund for AIDS Relief, which is for businesses run by people living with HIV and caregivers of orphans and vulnerable children.
Microfinance programs increase financial literacy and teach people valuable money management skills, according to Jeanette Thomas, communications director of the Consultative Group to Assist the Poor, a policy and research center associated with the World Bank Group.

"Financial management is fundamental to a household and it can help families manage day to day cash flow so that they can save for family events and emergencies - a health shock, a death in the family, educating the kids, or buying uniforms," Thomas writes in an email. "With the very poor/extreme poor, programs that combine other interventions, such as safety nets, food security, etc., with financial education, savings, and business development training can be quite successful. These programs are not just about loans for the poor, but more about how to manage money effectively for the household's immediate needs and growth out of poverty."
The independence born of increased financial literacy leads to many other benefits, says Alka Subramanian, executive director of Power of Love Foundation, a charity that has offered microloans to women affected by HIV/AIDS in Zambia since 2006. "Once they get a loan and start running a business, their whole view of the future changes. They see that they can earn money and provide for their families. They see that there is hope and want to do better for themselves and their families. They want their children to stay in school. They want to save for books. They realize they should themselves get tested for HIV," says Subramanian.

"One intangible we are very proud of is that the women have become role models for other women in the community," Subramanian adds. "And also role models for the men in the community." - Sanjeet Bagcchi MBBS, Kolkata, India, and Roger Collier, CMAJ

CMAJ 2012. DOI:10.1503/cmaj.109-4160 